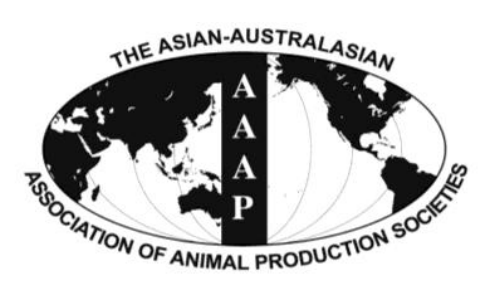

\title{
Citrus Pulp as a Dietary Source of Antioxidants for Lactating Holstein Cows Fed Highly Polyunsaturated Fatty Acid Diets
}

\author{
G. T. Santos*, L. S. Lima, A. L. B. Schogor, J. V. Romero, F. E. De Marchi, P. A. Grande, \\ N. W. Santos, F. S. Santos, and R. Kazama ${ }^{1}$ \\ Departamento de Zootecnia, Universidade Estadual de Maringá, Maringá PR 87020-900, Brazil
}

\begin{abstract}
The effects of feeding pelleted citrus pulp (PCP) as a natural antioxidant source on the performance and milk quality of dairy cows fed highly polyunsaturated fatty acid (FA) diets were evaluated. Four lactating Holstein cows were assigned to a $4 \times 4$ Latinsquare. Treatments, on a dry matter (DM) basis, were i) control diet; ii) 3\% soybean oil; iii) 3\% soybean oil and 9\% PCP and; iv) $3 \%$ soybean oil and $18 \%$ PCP. When cows fed on citrus pulp, the DM intake tended to decrease. The total tract apparent digestibility of DM and ether extract decreased when cows fed on the control diet compared to other diets. Cows fed PCP had higher polyphenols and flavonoids content and higher total ferric reducing antioxidant power (FRAP) in milk compared to those fed no pelleted citrus pulp. Cows fed 18\% PCP showed higher monounsaturated FA and lower saturated FA in milk fat compared with cows fed the other diets. The lowest n-6 FA proportion was in milk fat from cows fed control. The present study suggests that pelleted citrus pulp added to $9 \%$ to $18 \%$ DM increases total polyphenols and flavonoids concentration, and the FRAP in milk. (Key Words: Flavonoids, Polyphenols, Ferric Reducing Antioxidant Power)
\end{abstract}

\section{INTRODUCTION}

Recent research has focused on the importance of supplying lactating dairy cows with polyunsaturated fatty acids (FA). This is an established practice that helps meet the energy requirements. Moreover, polyunsaturated FA possesses many biological functions such as specific roles in cellular membrane structure and synthesis of prostaglandins (Grummer and Carroll, 1991). Furthermore, there is great interest in modulating milk fat composition through dietary polyunsaturated FA (Côrtes et al., 2010).

Soybean oil is rich in omega 6 linoleic acid (cis-18:2), which has been shown to increase conjugated linoleic acid concentration in milk fat when fed at $4 \%$ of dietary dry matter (DM) to dairy cows fed high-forage (59\% forage)

\footnotetext{
* Corresponding Author: Geraldo Tadeu dos Santos. Tel: +55-4430118947, Fax: +55-44-30118977, E-mail: gtsantos@uem.br

1 Departamento de Zootecnia e Desenvolvimento Rural, Universidade Federal de Santa Catarina, Florianópolis SC 88040900, Brazil.
}

Submitted Dec. 20, 2013; Revised Feb. 14, 2014; Accepted Mar. 27, 2014 diets (Bu et al., 2007). However, increasing polyunsaturated FA in the milk fat may render milk more susceptible to oxidative damages because fatty acids, especially polyunsaturated FA, are easily oxidized (Shiota et al., 1999). Thus, feeding cows with elevated dietary antioxidants may increase the transfer of these compounds from the diet to milk and protect polyunsaturated FA in milk from oxidation.

Citrus by-products are important components of ruminant feeding systems in many areas of the world, and are a source of dietary energy (Bampidis and Robinson, 2006). The main citrus by-product is citrus pulp, which can be fed fresh, dried, or as silage. Dried citrus pulp contains considerable amount of sugars (12\% to $40 \%)$ and neutral detergent-soluble fiber carbohydrates (22\% to $44 \%$ of DM) such as pectic substances (Sunvold et al., 1995; Hall et al., 2010).

Dried citrus pulp may be a good candidate for the partial replacement of highly fermentable grains in dairy cow rations, to assist in the protection against ruminal acidosis (Arthington et al., 2002), and may improve the efficiency of feed utilization for milk production (Miron et al., 2002). 
Assis et al. (2004) reported that citrus pulp can replace $100 \%$ of corn in diets of lactating cows averaging $20 \mathrm{~kg} / \mathrm{d}$ of milk. Santos et al. (2001) observed an increase in milk production when cows were fed citrus pulp as a corn grain substitute $(14 \%$ of DM) in total mixed ration.

Furthermore, citrus pulp is a source of flavonoids such as hesperidin and naringin (Bampidis and Robinson, 2006), which have been found to have antioxidant properties (Williams et al., 2004). Therefore, for cows fed diets with a high concentration of polyunsaturated FA citrus pulp may be useful to increase the amount of antioxidants in milk and to improve milk quality.

Thus, this study aimed to evaluate the effects of feeding pelleted citrus pulp as natural antioxidant source on the performance and milk quality of dairy cows fed highly polyunsaturated FA diets.

\section{MATERIAL AND METHODS}

This study was conducted at the experimental farm of the Universidade Estadual de Maringá, southern Brazil. Four multiparous lactating Holstein cows, averaging 164 days of milk production (standard error of the mean [SEM] $=21.8$ days) and $612 \mathrm{~kg}$ of body weight (body weight $[\mathrm{BW}]$; SEM $=41.5 \mathrm{~kg}$ ), were used in a $4 \times 4$ Latin-square design over four 21-d periods. The Animal Care and Use Committee of the Universidade Estadual de Maringá approved all animal procedures.

Treatments consisted of four different mixed diets (Table 1) composed of corn silage, ground corn, soybean meal, and mineral supplement, differing by the inclusion of soybean oil and by replacement of ground corn with citrus pulp (on a DM basis), as follows: i) control (CONT, without oil and pelleted citrus pulp); ii) 3\% of soybean oil (SBOIL); iii) $3 \%$ of soybean oil and $9 \%$ of citrus pulp (SOCP-9); and iv) $3 \%$ of soybean oil and $18 \%$ of pelleted citrus pulp (SOCP-18). Diets were formulated to meet the requirements for cows of $600 \mathrm{~kg}$ of BW and producing $25 \mathrm{~kg} / \mathrm{d}$ of milk containing $3.8 \mathrm{~g} / \mathrm{kg}$ of fat (NRC, 2001). Cows were housed in tie stalls, fed individually for ad libitum intake (10\% in orts) twice a day (7:00 and 14:00 h), and milked twice daily at 06:00 and 16:00 h. Milk production was recorded at every milking. The yield of $4 \%$ fat-corrected milk was calculated according to the equation of Tyrrell and Reid (1965). Cows were weighed on the first and last day of each experimental period and changes in body weight were calculated as the difference between these weights.

Samples of diets and orts were collected daily from day 15 to 21 , frozen, and pooled on a period basis. Composite samples were mixed thoroughly and sub-sampled for chemical analyses. Feces samples (100 g) were collected from day 15 to 20 at 26-h intervals, and then stored at $-20^{\circ} \mathrm{C}$ until use. These samples were pooled for each animal after drying $\left(55^{\circ} \mathrm{C}\right)$ for subsequent analysis.

Samples (food, orts, and feces) were oven-dried $\left(55^{\circ} \mathrm{C}\right.$ for $72 \mathrm{~h}$ ) and then ground in a cutter mill to pass through a 1-mm screen sieve. Dry matter was evaluated according to method no. 934.01 of the Association of Analytical Communities (AOAC, 1998). The organic matter was determined by combustion in a muffle furnace according to method no. 942.05 of AOAC (1998). Total nitrogen (TN) determination Tecnal TE-036/1 (Tecnal, Piracicaba, São Paulo, Brazil) following method no. 988.05 of the AOAC (1998) and crude protein (CP) was estimated as $\mathrm{TN} \times 6.25$. Ether extraction of diets was conducted with Tecnal TE044/1 according to the method no. 920.39 of AOAC (1998).

Table 1. Chemical composition of ingredients

\begin{tabular}{|c|c|c|c|c|c|}
\hline \multirow{2}{*}{ Item } & \multicolumn{5}{|c|}{ Ingredients $^{1}$} \\
\hline & Corn silage & Ground corn & Soybean meal & Citrus pulp & Soybean oil \\
\hline$\overline{\text { Dry matter }(\mathrm{DM}, \%)}$ & 30.57 & 88.22 & 88.15 & 94.5 & 100.0 \\
\hline Organic matter $(\%, \mathrm{DM})$ & 96.32 & 98.9 & 93.33 & 94.7 & 100.0 \\
\hline Crude protein $(\%, \mathrm{DM})$ & 6.5 & 8.43 & 50.68 & 6.0 & - \\
\hline NDICP & 18.6 & 8.5 & 1.4 & 6.7 & - \\
\hline $\mathrm{ADICP}$ & 12.0 & 3.7 & 0.8 & 5.0 & - \\
\hline Ether extract $(\%, \mathrm{DM})$ & 2.6 & 3.7 & 2.2 & 1.9 & 100.0 \\
\hline Neural detergent fiber $(\%, \mathrm{DM})$ & 47.7 & 16.0 & 13.9 & 19.1 & - \\
\hline Nonfibrous carbohydrates (\%, DM) & 39.5 & 70.8 & 26.6 & 67.7 & - \\
\hline Acid detergent fiber $(\%, \mathrm{DM})$ & 26.2 & 3.7 & 8.2 & 14.6 & - \\
\hline $\operatorname{Lignin}(\%, \mathrm{DM})$ & 2.5 & 0.9 & 0.7 & 0.8 & - \\
\hline Polyphenols (mg/100 g, DM) & ND & ND & ND & 78.4 & ND \\
\hline Flavonoids (mg/100 g, DM) & ND & ND & ND & 16.1 & ND \\
\hline Total digestible nutrients ${ }_{\text {est }}^{2}(\%, \mathrm{DM})$ & 71.0 & 86.2 & 80.8 & 86.0 & 184.0 \\
\hline Net energy for lactation $^{2}$ (Mcal $\left./ \mathrm{kg}, \mathrm{DM}\right)$ & 1.62 & 1.99 & 1.86 & 1.98 & 5.65 \\
\hline
\end{tabular}

NDICP $=$ neutral detergent insoluble crude protein $(\%, \mathrm{CP}) ;$ ADICP $=$ acid detergent insoluble crude protein $(\%, \mathrm{CP}) ; \mathrm{ND}$, not detected.

${ }^{1}$ Mean of 4 pooled samples prepared by compositing 7 daily samples collected from d 15 to 21 .

${ }^{2}$ Calculated using described equations by NRC (2001). 
The neutral detergent fiber (NDF) was evaluated as described by Mertens (2002) using a heat-stable $\alpha$-amylase, without using sodium sulfite. Procedures for NDF determination were adapted to the $A_{n k m}{ }^{200}$ filter bag technique. The NDF and lignin contents were determined according to method 973.18 of AOAC (1998).

Nonfibrous carbohydrates (NFC) were estimated according to the equations described by NRC (2001): NFC $(\%$ of $\mathrm{DM})=100-(\mathrm{CP}+$ ether extract $[\mathrm{EE}]+\mathrm{NDF}+\mathrm{ash})$ and the observed total digestible nutrient (TDN) were estimated according to the following equation: $\mathrm{TDN}=\mathrm{dCP}+(2.25 \mathrm{x}$ $\mathrm{dEE})+\mathrm{dNDF}+\mathrm{dNFC}$; where $\mathrm{dCP}=$ digestible $\mathrm{CP}, \mathrm{dEE}=$ digestible $\mathrm{EE}, \mathrm{dNDF}=$ digestible $\mathrm{NDF}$, and $\mathrm{dNFC}=$ digestible NFC.

Indigestible NDF (iNDF) was used as the internal marker to estimate the fecal output and total tract apparent digestibility. For iNDF analysis, $0.5 \mathrm{~g}(1 \mathrm{~mm})$ of periodic samples (fecal, orts, and feeds) were incubated in situ (144 h) in the rumen of a cow (fed corn silage based diet with forage to concentrate ratio of 60 to 40) within nylon bags (F57 Ankom) followed by neutral detergent analysis (Mertens, 2002) by using an Ankom ${ }^{200}$ Fiber Analyzer (Ankom Technology Corp., Fairport, NY, USA).
Milk samples were taken from each cow for four consecutive milkings (day 19 and 20) and pooled on a yield basis to obtain three milk samples per cow within the period One milk sample was stored at $4^{\circ} \mathrm{C}$ with a preservative (bronopol-B2) until analysis to determine the contents of protein, urea $\mathrm{N}$, lactose, and total solids. To perform FA profile and antioxidants analyses, two samples were kept frozen at $-20^{\circ} \mathrm{C}$, one without preservative and the other with $\mathrm{Na}$ azide $(0.2 \mathrm{~g} / \mathrm{kg})$.

Protein, lactose, total solids, and urea $\mathrm{N}$ concentrations in milk samples were analyzed by infrared spectrophotometry (Bentley model 2000; Bentley Instrument Inc., Chaska, MN, USA). Milk somatic cells counts (SCC) were obtained using an electronic counter (Somacount 500, Chaska, MN, USA) as described by Voltolini et al. (2001).

Fat in milk was separated by centrifugation as described by Murphy et al. (1995), and FA were methylated according to method 5509 of the International Organization for Standardization (ISO; 1978) using KOH/methanol (Synth, São Paulo, Brazil) and n-heptane (Vetec, Rio de Janeiro, Brazil). FA methyl esters were quantified using a gas chromatographer (Trace GC Ultra, Thermo Scientific, West

Table 2. Ingredient and chemical composition of total mixed diets

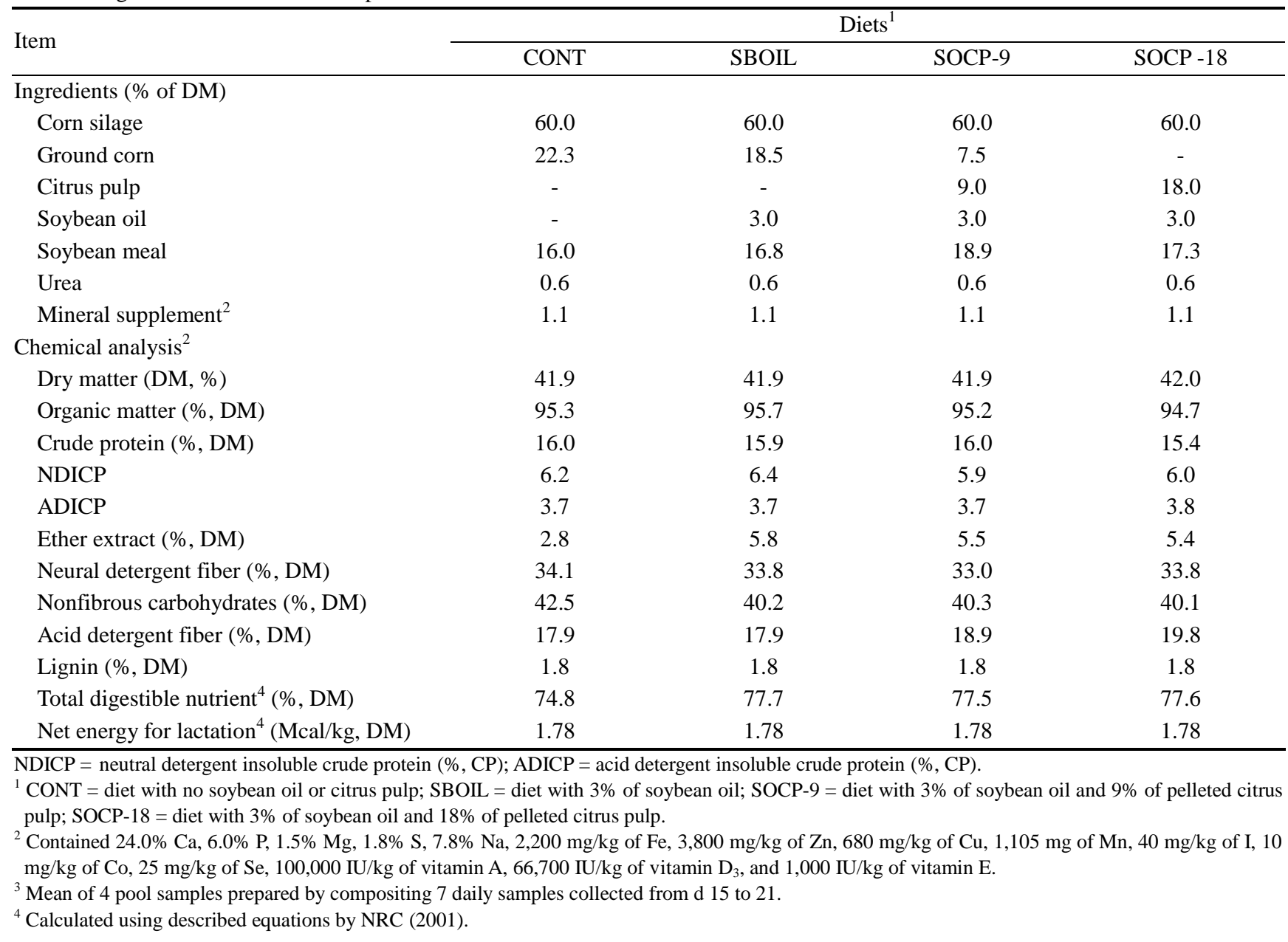


Palm Beach, FL, USA) equipped with an autosampler, a flame-ionization detector, and an Rt-2560 fused-silica capillary column $(100 \mathrm{~m} \times 0.25 \mathrm{~mm}$ i.d., $0.20 \mu \mathrm{m}$ film thickness). The column parameters were as follows: the initial column temperature of $65^{\circ} \mathrm{C}$ was maintained for 8 min; and the temperature was then programmed at $50^{\circ} \mathrm{C} / \mathrm{min}$ to $170^{\circ} \mathrm{C}$. This temperature was maintained for $40 \mathrm{~min}$ and increased by $50^{\circ} \mathrm{C} / \mathrm{min}$ to $240^{\circ} \mathrm{C}$, and then maintained at this temperature for $28.5 \mathrm{~min}$. The injector and detector temperatures were $220^{\circ} \mathrm{C}$ and $245^{\circ} \mathrm{C}$, respectively. The gas flow was $1.5 \mathrm{~mL} / \mathrm{min}$ of hydrogen (carrier gas), $30 \mathrm{~mL} / \mathrm{min}$ of $\mathrm{N}_{2}$ (auxiliary gas), and 35 $\mathrm{mL} / \mathrm{min}$ of $\mathrm{H}_{2}$ and $350 \mathrm{~mL} / \mathrm{min}$ of make-up gas (flame gases). FA peaks were identified using pure methyl ester standards (Sigma, São Paulo, Brazil).

Blood was collected from all cows on day 18 (08:00 h) after morning milking to determine very low-density lipoprotein (VLDL), low-density lipoprotein (LDL), highdensity lipoprotein (HDL), total cholesterol, triacylglycerols, glucose, and urea concentrations. Blood was withdrawn from the jugular vein into vacutainer tubes containing heparin. The tubes were immediately centrifuged for $20 \mathrm{~min}$ at $3,000 \times g$. Plasma was separated and frozen at $-20^{\circ} \mathrm{C}$ for subsequent analysis. Plasma triacylglycerol concentration was determined by an enzymatic colorimetric method using glycerol-3-phosphate oxidase at $500 \mathrm{~nm}$ (kit 15710; Diasys Diognostic Systems, Holzheim, Germany). The HDL and LDL concentrations were analyzed by colorimetric assays at $600 \mathrm{~nm}$ (kits 13521 and 14121, respectively; Diasys Diognostic Systems). The VLDL concentration was estimated by dividing triacylglycerol concentration by five as described by Friedewald et al. (1972). Concentrations of total cholesterol (kit 11300; Diasys Diognostic Systems) and glucose (kit 12500; Diasys Diognostic Systems) were analyzed at $500 \mathrm{~nm}$ using enzymatic photometric assays and urea concentration (kit 1301; Diasys Diognostic Systems) was determined at $340 \mathrm{~nm}$.

Total polyphenols in milk and citrus pulp were obtained by methanol extraction and quantified using the FolinCiocalteu reagent (Singleton and Rossi, 1965) and polyvinylpolypyrrolidone (Doner et al., 1993). The phenolic content is reported as gallic acid equivalents (GAE).

Flavonoids in milk and coffee hull were determined based on complexion by using aluminum chloride (Buriol et al., 2009). Quercetin was used as the standard to build the calibration curve and the results are reported as quercetin equivalents (EQ).

Samples were mixed with trichloroacetic acid (20\%) and maintained at rest for $10 \mathrm{~min}$, then centrifuged for 10 min at $1,058 \times g$ to determine the ferric reducing antioxidant power (FRAP). Milk antioxidant capacity was evaluated as described by Zhu et al. (2002). Gallic acid was used as the standard to build the calibration curve and the results are reported as GAE $(\mu \mathrm{g} / \mathrm{mL})$.

All the data from the experiments were analyzed as a $4 \times 4$ Latin-square design balanced for residual effect using the general llinear model procedure (SAS version 9.0) with the following model:

$$
\mathrm{Y}_{\mathrm{ijkl}}=\mu+\mathrm{C}_{\mathrm{j}}+\mathrm{P}_{\mathrm{k}}+\mathrm{T}_{\mathrm{l}}+\mathrm{e}_{\mathrm{ijk} \mathrm{l}}
$$

where $\mathrm{Y}_{\mathrm{ijkl}}=$ dependent variable, $\mu=$ overall mean, $\mathrm{C}_{\mathrm{j}}=$ random effect of cow ( $\mathrm{j}=1$ to 4$), \mathrm{P}_{\mathrm{k}}=$ fixed effect of period $(\mathrm{k}=1$ to 4$), \mathrm{T}_{1}=$ fixed effect of treatment $(1=$ control, soybean oil, soybean oil $+9 \%$ pelleted citrus pulp, soybean oil $+18 \%$ pelleted citrus pulp), and $\mathrm{e}_{\mathrm{ijk}}=$ random residual error. Significance was declared at $\mathrm{p} \leq 0.05$ and a trend at $0.05<\mathrm{p} \leq 0.10$, unless otherwise stated. When a significant $\mathrm{F}$ test was detected, multiple comparisons were done using the Tukey's adjustment of the probability.

\section{RESULTS}

No significant differences were observed for changes of body weight (Table 3$)$. A trend $(\mathrm{p}=0.081)$ of low DM intake $(\mathrm{kg} / \mathrm{d})$ was observed when cows were fed SOCP-9 and SOCP-18 compared with those fed CONT and SBOIL diets. However, dry matter intake expressed as a percentage of body weight did not differ among diets (Table 3). Intakes of CP protein, NDF, NFC, and total net energy for lactation were not affected by diets. However, EE intake increased in cows fed dietary soybean oil.

The digestibilities of DM and EE were lower for CONT compared to other diets (Table 3). There was a tendency ( $p$ $=0.068$ ) for lower CP digestibility for CONT diet. The digestibility of NDF did not differ among diets whereas NFC digestibility was higher for SOCP-9 and SOCP-18 than other diets. The CONT diet showed lower TDN percentage than other diets.

Milk production and $4 \%$ fat-corrected milk yield were similar among the treatments (Table 4). Concentrations of protein, lactose, and urea were also not affected. On the other hand, milk fat and total solids were higher for cows fed CONT than for cows fed other diets. Yields of protein, lactose, and total solids, and somatic cells count were similar among treatments. However, milk fat yield was lower for cows fed SBOIL, SOCP-9, and SOCP-18 than for cows fed CONT.

Milk from cows fed SOCP-18 diet had the highest total polyphenol concentration. Cows fed pelleted citrus pulp had higher flavonoid content and higher ferric reduction antioxidant power in milk than those fed no pelleted citrus pulp (Table 4).

Cows fed diets with supplemental oil had higher HDL, LDL, and total cholesterol concentration in the plasma than cows fed CONT diet (Table 4). 
Table 3. Changes in body weight, and intake, digestibility and total digestible nutrients of diets

\begin{tabular}{|c|c|c|c|c|c|c|}
\hline \multirow{2}{*}{ Item } & \multicolumn{4}{|c|}{ Diets $^{1}$} & \multirow{2}{*}{ SE } & \multirow{2}{*}{$\mathrm{p}$-value } \\
\hline & CONT & SBOIL & SOCP-9 & SOCP -18 & & \\
\hline Changes in body weight $(\mathrm{kg} / \mathrm{d})$ & 0.34 & 0.01 & 0.38 & 0.36 & 0.219 & 0.560 \\
\hline \multicolumn{7}{|l|}{ Intake } \\
\hline Dry matter (kg/d) & 18.4 & 18.3 & 16.5 & 16.2 & 0.74 & 0.081 \\
\hline Dry matter $(\mathrm{g} / \mathrm{kg}$ of $\mathrm{BW})$ & 2.9 & 3.1 & 2.9 & 2.4 & 0.05 & 0.250 \\
\hline Crude protein $(\mathrm{kg} / \mathrm{d})$ & 3.0 & 3.0 & 2.8 & 2.6 & 0.18 & 0.380 \\
\hline Ether extract $(\mathrm{kg} / \mathrm{d})$ & $0.5^{\mathrm{b}}$ & $1.1^{\mathrm{a}}$ & $0.9^{\mathrm{a}}$ & $0.9^{\mathrm{a}}$ & 0.06 & 0.001 \\
\hline Neutral detergent fiber $(\mathrm{kg} / \mathrm{d})$ & 6.0 & 6.0 & 5.3 & 5.2 & 0.43 & 0.427 \\
\hline Nonfibrous carbohydrates $(\mathrm{kg} / \mathrm{d})$ & 8.0 & 7.5 & 6.7 & 6.6 & 0.50 & 0.242 \\
\hline Total net energy for lactation $(\mathrm{Mcal} / \mathrm{d})^{2}$ & 29.7 & 32.5 & 29.7 & 29.9 & 1.87 & 0.677 \\
\hline \multicolumn{7}{|l|}{ Total tract apparent digestibility } \\
\hline Dry matter $(\%)$ & $70.4^{\mathrm{b}}$ & $72.7^{\mathrm{a}}$ & $74.1^{\mathrm{a}}$ & $75.4^{\mathrm{a}}$ & 0.87 & 0.015 \\
\hline Crude protein $(\%)$ & 71.3 & 72.7 & 75.9 & 76.5 & 1.30 & 0.068 \\
\hline Ether extract (\%) & $73.6^{\mathrm{b}}$ & $90.8^{\mathrm{a}}$ & $90.9^{\mathrm{a}}$ & $92.7^{\mathrm{a}}$ & 1.16 & 0.050 \\
\hline Neutral detergent fiber $(\%)$ & 56.1 & 58.7 & 57.4 & 57.6 & 2.43 & 0.896 \\
\hline Nonfibrous carbohydrates (\%) & $83.4^{\mathrm{c}}$ & $85.2^{\mathrm{bc}}$ & $87.9^{\mathrm{b}}$ & $92.4^{\mathrm{a}}$ & 0.97 & 0.001 \\
\hline Total digestible nutrient $(\%)$ & $70.9^{\mathrm{b}}$ & $77.6^{\mathrm{a}}$ & $78.5^{\mathrm{a}}$ & $80.3^{\mathrm{a}}$ & 0.94 & 0.001 \\
\hline
\end{tabular}

SE, standard error; BW, body weight.

${ }^{1}$ CONT $=$ diet with no soybean oil or pelleted citrus pulp; SBOIL = diet with $3 \%$ of soybean oil; SOCP-9 = diet with $3 \%$ of soybean oil and $9 \%$ of pelleted citrus pulp; SOCP-18 = diet with $3 \%$ of soybean oil and $18 \%$ of pelleted citrus pulp.

${ }^{2}$ Estimated according to NRC (2001) using data on total digestible nutrient intake.

Means within a row with different superscripts differ at $\mathrm{p} \leq 0.05$.

Milk fat from cows fed diets with soybean oil tended to contain less $(p=0.09)$ 4:0 and 6:0 FA than the milk fat from cows fed CONT diet (Table 5). The proportion of 8:0 FA was higher in milk fat of cows fed diets with citrus pulp while milk fat of cows fed CONT diet had higher 10:0 FA. Cows fed citrus pulp had high 11:0 FA in milk fat when compared with those fed CONT and SBOIL diets. Higher proportion of cis7-16:1 FA and lower proportion of 18:0 FA were found in milk fat from cows fed SOCP-18. In general, cows fed SOCP-18 showed higher monounsaturated FA and lower saturated FA than cows fed the other diets. The lowest n-6 FA proportion was found in milk fat from cows fed CONT.

\section{DISCUSSION}

In the present study, experimental diets did not significantly affect changes in body weight. It suggests that, despite of the different diet ingredients composition that included fat supplementation, rations provided animals with similar amounts of energy. Thus, animals likely had sufficient dietary energy to meet maintenance and production requirements. This is supported by the lack of effect on total net energy intake and milk production that we observed. Pelleted citrus pulp caused the decrease of DM intake. A similar reduction in DM intake has been shown for highly producing dairy cows fed citrus pulp as a corn grain substitute in total mixed rations (Solomon et al., 2000). Hall et al. (2010) and Miron et al. (2002) also observed lower DM intake in cows fed citrus pulp in total mixed ration. It is suggested that pectin, which is abundant (22\% to $40 \%$ ) in the citrus pulp (Sunvold et al., 1995; Arthington et al., 2002), could interfere with ruminal fermentation resulting in greater rumen fill. This is supported by the slightly higher ruminal rate and extent of degradability of starch compared to pectin (Van Soest, 1994). The density of citrus pulp after hydration in the rumen could also help to explain the observed effects on DM intake. Indeed, hydration has been reported to promote swelling of citrus pulp (Bampidis and Robinson, 2006) and it may have accounted for the reduction of feed intake of total mixed ration due to a possible higher rumen fill.

Over the years, it has been well known that supplemental polyunsaturated FA affects fiber digestion due to negative effects of polyunsaturated FA on the rumen microbial population that are involved with cellulose digestion (Jenkins, 1993; Yang et al., 2009). In the present study, the large amount of polyunsaturated FA in diets was expected to interfere with fiber digestibility. However, such an effect was not observed as suggested by results for NDF digestibility. Similar results have been previously reported (Bateman and Jenkins, 1998) in a study performed with nonlactating cows fed different dietary concentration of soybean oil $(2 \%$ to $8 \%)$. Authors have explained these effects as being based on a possible prompted rapid hydrolysis of soybean oil and subsequent hydrogenation of free FA promoted by high dietary concentrations of fiber that could prevent a serious disruption of ruminal 
Table 4. Milk production, milk composition and blood composition

\begin{tabular}{|c|c|c|c|c|c|c|}
\hline \multirow{2}{*}{ Item } & \multicolumn{4}{|c|}{ Diets $^{1}$} & \multirow{2}{*}{ SE } & \multirow{2}{*}{ p-value } \\
\hline & CONT & SBOIL & SOCP-9 & SOCP -18 & & \\
\hline Milk production $(\mathrm{kg} / \mathrm{d})$ & 22.7 & 23.4 & 23.8 & 24.7 & 1.83 & 0.892 \\
\hline $4 \%$ FCM $(\mathrm{kg} / \mathrm{d})$ & 20.0 & 18.6 & 18.1 & 20.1 & 1.67 & 0.794 \\
\hline \multicolumn{7}{|l|}{ Milk composition (\%) } \\
\hline Protein & 3.1 & 3.2 & 3.1 & 3.2 & 0.19 & 0.997 \\
\hline Fat & $3.4^{\mathrm{a}}$ & $2.6^{\mathrm{b}}$ & $2.4^{\mathrm{b}}$ & $2.4^{\mathrm{b}}$ & 0.25 & 0.050 \\
\hline TS & $12.2^{\mathrm{a}}$ & $11.4^{\mathrm{b}}$ & $11.1^{\mathrm{b}}$ & $11.1^{\mathrm{b}}$ & 0.14 & 0.001 \\
\hline Lactose & 4.7 & 4.7 & 4.6 & 4.6 & 0.06 & 0.829 \\
\hline \multicolumn{7}{|l|}{ Milk yield $(\mathrm{kg} / \mathrm{d})$} \\
\hline Protein & 0.76 & 0.78 & 0.78 & 0.75 & 0.14 & 0.999 \\
\hline Fat & $0.8^{\mathrm{a}}$ & $0.6^{\mathrm{b}}$ & $0.6^{\mathrm{b}}$ & $0.6^{\mathrm{b}}$ & 0.05 & 0.010 \\
\hline TS & 3.0 & 2.8 & 2.7 & 2.6 & 0.48 & 0.872 \\
\hline Lactose & 1.1 & 1.1 & 1.1 & 1.1 & 0.14 & 0.986 \\
\hline Urea $N(\mathrm{mg} / \mathrm{dL})$ & 12.7 & 13.9 & 14.2 & 11.6 & 0.92 & 0.245 \\
\hline $\operatorname{SCS}\left(\log _{10} \mathrm{SCC}\right)$ & 2.3 & 2.2 & 2.3 & 2.3 & 0.10 & 0.903 \\
\hline Total polyphenols ${ }^{2}$ & $22.8^{\mathrm{b}}$ & $25.1^{\mathrm{b}}$ & $27.2^{\mathrm{ab}}$ & $31.1^{\mathrm{a}}$ & 0.87 & 0.001 \\
\hline Flavonoids $^{3}$ & $0.6^{\mathrm{b}}$ & $0.7^{\mathrm{b}}$ & $0.8^{\mathrm{a}}$ & $0.8^{\mathrm{a}}$ & 0.53 & 0.089 \\
\hline FRAP & $11.5^{\mathrm{b}}$ & $11.1^{\mathrm{b}}$ & $25.0^{\mathrm{a}}$ & $28.1^{\mathrm{a}}$ & 3.17 & 0.007 \\
\hline \multicolumn{7}{|c|}{ Plasma concentration $(\mathrm{mg} / \mathrm{dL})$} \\
\hline Glucose & 67.8 & 68.0 & 67.3 & 67.8 & 1.56 & 0.992 \\
\hline Triacylglycerol & 8.0 & 10.0 & 11.5 & 12.8 & 2.11 & 0.461 \\
\hline HDL & $73.0^{\mathrm{b}}$ & $90.5^{\mathrm{a}}$ & $90.8^{\mathrm{a}}$ & $89.5^{\mathrm{a}}$ & 4.43 & 0.050 \\
\hline LDL & $30.0^{\mathrm{b}}$ & $65.3^{\mathrm{a}}$ & $63.5^{\mathrm{a}}$ & $78.0^{\mathrm{a}}$ & 8.6 & 0.024 \\
\hline VLDL & 1.6 & 2.0 & 2.3 & 2.6 & 0.45 & 0.483 \\
\hline Total cholesterol & $104.5^{\mathrm{b}}$ & $157.8^{\mathrm{a}}$ & $156.5^{\mathrm{a}}$ & $170.3^{\mathrm{a}}$ & 12.27 & 0.023 \\
\hline
\end{tabular}

SE, standard error; FCM, fat corrected milk; TS, total solids; SCS, somatic cell score $=\log _{10}$ (somatic cell count); FRAP, ferric reducing antioxidant power ( $\mu \mathrm{g} \mathrm{GAE} / \mathrm{mL})$; HDL, high-density lipoprotein; LDL, low-density lipoprotein; VLDL, very low-density lipoprotein; GAE, gallic acid equivalents; EQ, equivalents.

${ }^{1} \mathrm{CONT}=$ diet with no soybean oil or pelleted citrus pulp; SBOIL $=$ diet with $3 \%$ of soybean oil; SOCP-9 $=$ diet with $3 \%$ of soybean oil and $9 \%$ of pelleted citrus pulp; SOCP-18 = diet with $3 \%$ of soybean oil and $18 \%$ of pelleted citrus pulp.

${ }^{2}$ Total polyphenols: $\mu \mathrm{g}$ GAE $/ \mathrm{mL} .{ }^{3}$ Flavonoids: $\mu \mathrm{g} \mathrm{EQ} / \mathrm{mL}$.

Means within a row with different superscripts differ at $\mathrm{p} \leq 0.05$.

digestibility. Indeed, rate of lipolysis and hydrogenation have been reported to increase as dietary fiber increased (Jenkins, 1993). In the present study, dietary NDF concentration averaged $34 \%$, and this is similar to the lowest NDF level (35\%) evaluated by Bateman and Jenkins (1998). It suggests that dietary fiber content could also have interfered with ruminal lipid metabolism promoting higher FA hydrogenation. A possible higher ruminal hydrogenation of FA is supported by the milk FA profile which was barely changed by treatments. Furthermore, the dietary EE concentration $(5.6 \%)$ of diets containing soybean oil could also help to explain, at least partially, the lack of effect on NDF digestibility as it did not exceed recommended limits (6\% to $7 \%$ ) to avoid digestion problems (Palmquist and Jenkins, 1980; NRC, 2001).

In the present study, cows fed supplemental oil had higher EE digestibility, suggesting that dietary soybean oil improved fat utilization. It has been well recognized that fat digestion is influenced by factors such as the amount of fat consumed and the degree of saturation, the former being considered the most important aspect (NRC, 2001). Additionally, unsaturated FA have been reported to be more digestible than saturated FA (Borsting et al., 1992). Thus, the observed increase in EE intake and the lower degree of saturation of fat from diets containing soybean oil could explain the higher EE digestibility in diets with soybean oil.

In our study, dietary pelleted citrus pulp increased digestibilities of nonfibrous carbohydrate and CP. Similar effects have been previously observed by Miron et al. (2002) who reported that replacement of dietary corn by dried citrus pulp in lactating cows fed total mixed ration increased digestibility of neutral detergent-soluble carbohydrates and the digestibility of CP. These authors suggest that citrus pulp supplementation for lactating cows fed total mixed ration apparently creates favorable conditions for cellulolysis in the rumen, as expressed by the higher digestion of neutral detergent-soluble carbohydrates and CP (Miron et al., 2002). This finding is also supported 
Table 5. Fatty acid profile in milk ( $\mathrm{g} / \mathrm{kg}$ of total fatty acid) of Holstein cows fed experimental diets

\begin{tabular}{|c|c|c|c|c|c|c|}
\hline \multirow{2}{*}{ Item } & \multicolumn{4}{|c|}{ Diets $^{1}$} & \multirow{2}{*}{ SE } & \multirow{2}{*}{ p-value } \\
\hline & CONT & SBOIL & SOCP-9 & SOCP - 18 & & \\
\hline \multicolumn{7}{|l|}{ Intake } \\
\hline $4: 0$ & 6.6 & 5.7 & 4.2 & 4.3 & 0.65 & 0.09 \\
\hline $6: 0$ & 8.5 & 7.1 & 6.3 & 6.1 & 0.57 & 0.09 \\
\hline $8: 0$ & $5.9^{\mathrm{b}}$ & $6.3^{\mathrm{b}}$ & $6.5^{\mathrm{b}}$ & $9.2^{\mathrm{a}}$ & 0.32 & 0.001 \\
\hline 10:0 & $18.7^{\mathrm{a}}$ & $12.0^{\mathrm{b}}$ & $10.9^{\mathrm{b}}$ & $12.1^{\mathrm{b}}$ & 1.62 & 0.05 \\
\hline 11:0 & $3.9^{\mathrm{b}}$ & $1.8^{\mathrm{b}}$ & $7.8^{\mathrm{a}}$ & $6.8^{\mathrm{a}}$ & 1.21 & 0.02 \\
\hline $12: 0$ & 18.6 & 15.7 & 19.7 & 16.4 & 1.80 & 0.43 \\
\hline $13: 0$ & 0.8 & 0.8 & 0.5 & 1.0 & 0.12 & 0.14 \\
\hline $14: 0$ & 71.4 & 62.4 & 65.4 & 59.6 & 5.18 & 0.47 \\
\hline cis-9 14:1 & 6.3 & 3.8 & 5.0 & 6.3 & 1.29 & 0.52 \\
\hline $15: 0$ & 9.1 & 9.9 & 11.4 & 11.3 & 0.54 & 0.06 \\
\hline $16: 0$ & 159.5 & 153.4 & 167.0 & 166.0 & 7.75 & 0.58 \\
\hline cis7-16:1 & $4.1 \mathrm{~b}$ & $2.0 \mathrm{c}$ & $3.6 \mathrm{~b}$ & $6.8 \mathrm{a}$ & 0.65 & 0.003 \\
\hline cis9-16:1 & 7.1 & 5.6 & 5.6 & 7.7 & 0.83 & 0.19 \\
\hline $17: 0$ & $7.4^{\mathrm{a}}$ & $5.3^{\mathrm{ab}}$ & $5.0^{\mathrm{ab}}$ & $3.6^{\mathrm{b}}$ & 0.73 & 0.05 \\
\hline $17: 1$ & 2.6 & 1.7 & 2.3 & 1.7 & 0.24 & 0.06 \\
\hline 18:0 & $228.4^{\mathrm{a}}$ & $248.1^{\mathrm{a}}$ & $215.9^{\mathrm{a}}$ & $181.7^{\mathrm{b}}$ & 8.45 & 0.006 \\
\hline cis9-18:1 & 315.1 & 332.3 & 330.4 & 347.4 & 8.75 & 0.13 \\
\hline trans $9-18: 1$ & 30.8 & 23.3 & 28.4 & 44.9 & 5.35 & 0.11 \\
\hline cis $9,12-18: 2$ & 30.2 & 33.0 & 38.9 & 34.6 & 2.59 & 0.21 \\
\hline trans $9,12-18: 2$ & 2.9 & 3.6 & 3.2 & 3.3 & 0.48 & 0.76 \\
\hline cis6,9,12-18:3 & 0.2 & 5.7 & 2.3 & 7.1 & 2.11 & 0.19 \\
\hline cis $9,12,15-18: 3$ & 7.1 & 8.2 & 8.2 & 8.1 & 1.46 & 0.86 \\
\hline cis 9, trans $11-18: 2$ & 23.3 & 24.6 & 22.3 & 23.6 & 2.01 & 0.88 \\
\hline $20: 0$ & 8.3 & 7.0 & 5.7 & 7.8 & 0.39 & 0.02 \\
\hline cis $9,20: 1$ & 2.6 & 2.8 & 3.0 & 2.5 & 0.27 & 0.10 \\
\hline cis $8,11,14-20: 3$ & 1.0 & 1.5 & 1.5 & 2.8 & 0.48 & 0.15 \\
\hline cis $5,8,11,14-20: 4$ & 1.8 & 2.2 & 2.2 & 2.0 & 0.21 & 0.49 \\
\hline Others $^{2}$ & 18.0 & 14.3 & 16.7 & 15.4 & 1.64 & 0.64 \\
\hline Total trans & 57.0 & 51.4 & 53.9 & 71.9 & 7.37 & 0.28 \\
\hline MUFA & $375.5^{\mathrm{b}}$ & $377.5^{\mathrm{b}}$ & $385.1^{\mathrm{b}}$ & $423.7^{\mathrm{a}}$ & 7.37 & 0.002 \\
\hline PUFA & 71.4 & 81.2 & 81.4 & 86.7 & 5.78 & 0.38 \\
\hline SFA & $553.1^{\mathrm{a}}$ & $541.3^{\mathrm{a}}$ & $533.6^{\mathrm{a}}$ & $489.5^{\mathrm{b}}$ & 10.85 & 0.03 \\
\hline$n-3^{3}$ & 9.0 & 9.7 & 10.2 & 11.9 & 1.32 & 0.38 \\
\hline$n-6^{4}$ & $36.0^{\mathrm{b}}$ & $45.9^{\mathrm{a}}$ & $48.1^{\mathrm{a}}$ & $49.8^{\mathrm{a}}$ & 2.67 & 0.04 \\
\hline
\end{tabular}

SE, standard error; MUFA, monounsaturated fatty acids; PUFA, polyunsaturated fatty acids; SFA, saturated fatty acids.

${ }^{1}$ CONT $=$ diet with no soybean oil or pelleted citrus pulp; SBOIL = diet with $3 \%$ of soybean oil; SOCP-9 = diet with $3 \%$ of soybean oil and $9 \%$ of pelleted citrus pulp; SOCP-18 = diet with $3 \%$ of soybean oil and $18 \%$ of pelleted citrus pulp.

${ }^{2}$ Others $=21: 0+20: 2+22: 0+$ cis $13-22: 1+23: 0+$ cis $13,16-22: 2+24: 0+$ cis $5,8,11,14,17-20: 5+$ cis $15-24: 1+$ cis $4,7,10,13,16,19-22: 6$.

${ }^{3}$ cis $9,12,15-18: 3+$ cis $5,8,11,14,17-20: 5+22: 5$.

${ }^{4}$ cis $9,12-18: 2+$ cis6,9,12-18:3+cis $11,14-20: 2+$ cis8, 11,14-20:3+cis5,8,11,14-20:4.

Means within a row with different superscripts differ at $\mathrm{p} \leq 0.05$.

by Kim et al. (2007) who also reported that citrus pulp supplementation may improve $\mathrm{N}$ utilization in ruminants. The increased digestibility of nutrients (EE, NFC, and CP) likely accounted for the high dry matter digestibility and TDN that we observed in case of SBOIL, SOPC-9, and SOPC-18 compared with CONT diet.

In the present study, fat concentration was reduced in milk from cows fed dietary soybean oil whereas milk production was not affected. This effect is usually considered as milk fat depression (Bauman and Griinari, 2003) and is probably a consequence of the high proportion of dietary 18:2 FA provided by in soybean oil. Indeed, it has been well recognized that higher dietary polyunsaturated FA, such as 18:2, affect certain aspects of milk fat synthesis reducing its proportion in milk of dairy cows (Palmquist et al., 1993; Chilliard et al., 2000). Some authors have explained these effects with the "biohydrogenation theory" which tells that high dietary unprotected plant oils alter the 
pathways of rumen biohydrogenation to produce unique fatty acid intermediates, some of which are potent inhibitors of milk fat synthesis (Bauman and Griinari, 2001). Among these fatty acids intermediates, trans10, cis12-18:2, and trans10-18:1 have been reported to inhibit milk fat synthesis in the mammary gland (Baumgard et al., 2000; Piperova et al., 2000; Shingfield et al., 2010), and the former has been reported to have a more potent inhibitory effect on mammary de novo synthesis (Jenkins and McGuire, 2006).

There is a lack of information regarding the effects of dietary citrus pulp on milk antioxidants in dairy cattle. In the present study, dietary citrus pulp led to increased ferric reduction antioxidant power. It is suggested that citrus pulp antioxidants have been transferred from the diet to the milk, which is supported by the increased total polyphenols and flavonoids observed in milk from cows fed citrus pulp. Indeed, there is a relationship between the amount of total phenolic compounds and ferric reduction antioxidant power (Zhu et al., 2002). Although the total concentration of polyphenols and flavonoids is not quantitatively important as that of other milk components such as fat and protein that are very potent substances with antioxidant and antiinflammatory bioactivities (Dai and Mumper, 2010). Furthermore, in vitro and in vivo studies have showed that they exert neuroprotection at high or low doses (Hwang et al., 2012).

Soybean oil supplementation increased VLDL, LDL, and total cholesterol levels in the plasma. This may be explained by the physiological response of the organism to support the transport of the larger amounts of lipids provided by oil supplementation (Rindsig and Schultz, 1974). Indeed, as previously reported by Grummer and Carroll (1991) and Weiss and Wyatt (2003) lipid supplementation has been shown to increase plasma cholesterol levels.

Milk fat FA profile was barely altered by treatments. Most of the changes were observed for short- and mediumchain FA, such as C4, C6, C10, and C16 FA. Dietary citrus pulp tended to decrease 4:0 FA in milk which agrees with the results reported by Fegeros et al. (1995) who fed dried citrus pulp to ewes. This FA is derived from butyrate, which is synthetized in the rumen, and it is not dependent on the de novo synthesis to be secreted in the milk (Fox and McSweeney, 1998). Then, it is suggested that possible changes in rumen butyrate synthesis may have interfered with milk $\mathrm{C} 4: 0$ content. However, the effects of dietary citrus pulp on ruminal synthesis of butyrate vary in different ruminant species. For example, in studies with small ruminants fed dried citrus pulp-based diets, a decrease in ruminal butyrate concentration was observed (Piquer et al., 2009; Gilaverte et al., 2011). In contrast, an increase in ruminal butyrate concentration was observed in dairy cows fed diets containing dried citrus pulp (Broderick and
Clayton, 1997; Rocha Filho et al., 1999). Then, it is suggested that the effects of citrus pulp on milk $\mathrm{C} 4: 0$ content seem to depend on other factors such as the other ingredients in the total mixed ration.

In this study, $18 \%$ DM pelleted citrus pulp supplementation led to lower 18:0 FA content in milk. Highly polyunsaturated FA are usually extensively biohydrogenated in the rumen (Kalscheur et al., 1997; Bateman and Jenkins, 1998) and citrus pulp seems to have interfered with ruminal biohydrogenation, thus resulting in incomplete processes that produce trans-18:1 FA isomers. This is supported by the observed tendency to increase milk fat trans9-18:1 concentration. Furthermore, these changes likely accounted for the higher monounsaturated FA and lower saturated FA content observed in milk fat from cows fed $18 \%$ DM of pelleted citrus pulp.

In conclusion, the present study suggests that the addition of $9 \%$ and $18 \%$ of pelleted citrus pulp to normal diets increases the total polyphenol and flavonoid concentration, and ferric reduction antioxidant power in milk from cows fed highly polyunsaturated FA. Furthermore, although pelleted citrus pulp reduces the DM intake, it can be used as a corn grain substitute $(9 \%$ and $18 \%$ DM) without negatively affecting the nutritional value of total mixed ratios, milk production, and milk quality of dairy cows fed highly polyunsaturated FA diets.

\section{ACKNOWLEDGMENTS}

The present study was funded by Conselho Nacional de Desenvolvimento Científico e Tecnológico - CNPq (Brasília, DF, Brazil). The authors express their gratitude to the staff of Universidade Estadual de Maringá (Maringá, PR, Brazil) for their contribution to the present study. We especially want to thank the Associação de Criadores de Bovinos da Raça Holandesa - APCBRH (Curitiba, PR, Brazil) for its assistance in milk analysis.

\section{REFERENCES}

AOAC. 1998. Official Methods of Analysis. 16th edn. Association of Official Analytical Chemists, Gaithersburg, MD, USA.

Arthington, J. D., W. E. Kunkle, and A. M. Martin. 2002. Citrus pulp for cattle. Vet. Clin. North Am. Food Anim. Pract. 18:317-326.

Assis, A. J., J. M. D. Campos, S. D. Valadares, A. C. de Queiroz, R. D. Lana, R. F. Euclydes, J. M. Neto, A. L. R. Magalhaes, and S. D. Mendonca. 2004. Citrus pulp in diets for milking cows. Intake of nutrients, milk production and composition. R. Bras. Zootec. 33:242-250.

Bampidis, V. A. and P. H. Robinson. 2006. Citrus by-products as ruminant feeds: A review. Anim. Feed Sci. Technol. 128:175217.

Bateman, H. G. and T. C. Jenkins. 1998. Influence of soybean oil in high fiber diets fed to nonlactating cows on ruminal 
unsaturated fatty acids and nutrient digestibility. J. Dairy Sci. 81:2451-2458.

Bauman, D. E. and J. M. Griinari. 2001. Regulation and nutritional manipulation of milk fat: low-fat milk syndrome. Livest. Prod. Sci. 70:15-29.

Bauman, D. E. and J. M. Griinari. 2003. Nutritional regulation of milk fat synthesis. Annu. Rev. Nutr. 23:203-227.

Baumgard, L. H., B. A. Corl, D. A. Dwyer, A. Saebo, and D. E. Bauman. 2000. Identification of the conjugated linoleic acid isomer that inhibits milk fat synthesis. Am. J. Physiol. Regul. Integr. Comp. Physiol. 278:179-184.

Borsting, C. F., M. R. Weisbjerg, and T. Hvelplund. 1992. Fattyacid digestibility in lactating cows fed increasing amounts of protected vegetable oil, fish oil or saturated fat. Acta Agric. Scand. Sect. A Anim. Sci. 42:148-156.

Broderick, G. A. and M. K. Clayton. 1997. A statistical evaluation of animal and nutritional factors influencing concentrations of milk urea nitrogen. J. Dairy Sci. 80:2964-2971.

Bu, D. P., J. Q. Wang, T. R. Dhiman, and S. J. Liu. 2007. Effectiveness of oils rich in linoleic and linolenic acids to enhance conjugated linoleic acid in milk from dairy cows. J. Dairy Sci. 90:998-1007.

Buriol, L., D. Finger, E. M. Schmidt, J. M. T. dos Santos, M. R. da Rosa, S. P. Quináia, Y. R. Torres, H. S. Dalla Santa, C. Pessoa, M. O. de Moraes, L. V. Costa-Lotufo, P. M. P. Ferreira, A. C. H. F. Sawaya, and M. N. Eberlin. 2009. Chemical composition and biological activity of oil propolis extract: An alternative to ethanolic extract. Quim. Nova 32:296-302.

Chilliard, Y., A. Ferlay, R. M. Mansbridge, and M. Doreau. 2000. Ruminant milk fat plasticity: Nutritional control of saturated, polyunsaturated, trans and conjugated fatty acids. Ann. Zootech. 49:181-205.

Côrtes, C., D. C. da Silva-Kazama, R. Kazama, N. Gagnon, C. Benchaar, G. T. Santos, L. M. Zeoula, and H. V. Petit. 2010. Milk composition, milk fatty acid profile, digestion, and ruminal fermentation in dairy cows fed whole flaxseed and calcium salts of flaxseed oil. J. Dairy Sci. 93:3146-3157.

Dai, J. and R. J. Mumper. 2010. Plant phenolics: extraction, analysis and their antioxidant and anticancer properties. Molecules 15:7313-7352.

Doner, L. W., G. Becard, and P. L. Irwin. 1993. Binding of flavonoids by polyvinylpolypyrrolidone. J. Agric. Food Chem. 41:753-757.

Fegeros, K., G. Zervas, S. Stamouli, and E. Apostolaki. 1995 Nutritive-value of dried citrus pulp and its effect on milk-yield and milk-composition of lactating ewes. J. Dairy Sci. 78:11161121.

Fox, P. F. and P. L. H. McSweeney. 1998. Dairy Chemistry and Biochemistry. Blackie Academic and Professional, Great Britain.

Friedewald, W. T., R. I. Levy, and D. S. Fredrickson. 1972. Estimation of the concentration of low-density lipoprotein cholesterol in plasma, without use of the preparative ultracentrifuge. Clin. Chem. 18:499-502.

Gilaverte, S., I. Susin, A. V. Pires, E. M. Ferreira, C. Q. Mendes, R. S. Gentil, M. V. Biehl, and G. H. Rodrigues. 2011. Diet digestibility, ruminal parameters and performance of Santa Ines sheep fed dried citrus pulp and wet brewer grain. R. Bras. Zootec. 40:639-647.
Grummer, R. R. and D. J. Carroll. 1991. Effects of dietary fat on metabolic disorders and reproductive performance of dairy cattle. J. Anim. Sci. 69:3838-3852.

Hall, M. B., C. C. Larson, and C. J. Wilcox. 2010. Carbohydrate source and protein degradability alter lactation, ruminal, and blood measures. J. Dairy Sci. 93:311-322.

Hwang, S.-L., P.-H. Shih, and G.-C. Yen. 2012. Neuroprotective effects of citrus flavonoids. J. Agric. Food Chem. 60:877-885.

International Organization for Standardization. 1978. Animal and vegetable fats and oils - Preparation of methyl esters of fatty acids, London.

Jenkins, T. C. 1993. Lipid metabolism in the rumen. J. Dairy Sci. 76:3851-3863.

Jenkins, T. C. and M. A. McGuire. 2006. Major advances in nutrition: Impact on milk composition. J. Dairy Sci. 89:13021310.

Kalscheur, K. F., B. B. Teter, L. S. Piperova, and R. A. Erdman. 1997. Effect of fat source on duodenal flow of trans- $\mathrm{C}_{18: 1}$ fatty acids and milk fat production in dairy cows. J. Dairy Sci. 80:2115-2126.

Kim, S. C., A. T. Adesogan, and J. D. Arthington. 2007. Optimizing nitrogen utilization in growing steers fed forage diets supplemented with dried citrus pulp. J. Anim. Sci. 85:2548-2555.

Mertens, D. R. 2002. Gravimetric determination of amylasetreated neutral detergent fiber in feeds with refluxing in beakers or crucibles: Collaborative study. J. AOAC Int. 85:1217-1240.

Miron, J., E. Yosef, D. Ben-Ghedalia, L. E. Chase, D. E. Bauman, and R. Solomon. 2002. Digestibility by dairy cows of monosaccharide constituents in total mixed rations containing citrus pulp. J. Dairy Sci. 85:89-94.

Murphy, J. J., J. F. Connolly, and G. P. McNeill. 1995. Effects on milk fat composition and cow performance of feeding concentrates containing full fat rapeseed and maize distillers grains on grass-silage based diets. Livest. Prod. Sci. 44:1-11.

National Research Council. 2001. Nutrients Requirements of Dairy Cattle. 7th Ed. National Academies Press, Washington, DC, USA.

Palmquist, D. L., A. D. Beaulieu, and D. M. Barbano. 1993. Feed and animal factors influencing milk fat composition. J. Dairy Sci. 76:1753-1771.

Palmquist, D. L. and T. C. Jenkins. 1980. Fat in lactation rations: Review. J. Dairy Sci. 63:1-14.

Piperova, L. S., B. B. Teter, I. Bruckental, J. Sampugna, S. E. Mills, M. P. Yurawecz, J. Fritsche, K. Ku, and R. A. Erdman. 2000. Mammary lipogenic enzyme activity, trans fatty acids and conjugated linoleic acids are altered in lactating dairy cows fed a milk fat-depressing diet. J. Nutr. 130:2568-2574.

Piquer, O., L. Ródenas, C. Casado, E. Blas, and J. J. Pascual. 2009 Whole citrus fruits as an alternative to wheat grain or citrus pulp in sheep diet: Effect on the evolution of ruminal parameters. Small Rumin. Res. 83:14-21.

Rindsig, R. B. and L. H. Schultz. 1974. Effects of abomasal infusions of safflower oil or elaidic acid on blood lipids and milk fat in dairy cows. J. Dairy Sci. 57:1459-1466.

Rocha Filho, R. R., P. F. Machado, R. D. D'Arce, and J. C. Francisco Jr. 1999. Citrus and corn pulp related to rumen volatile fatty acids production. Sci. Agric. 56:471-477. 
Santos, F. A. P., M. P. Menezes Júnior, J. M. C. Simas, A. V. Pires, and C. M. B. Nussio. 2001. Corn grain processing and its partial replacement by pelleted citrus pulp on performance, nutrient digestibility and blood parameters of dairy cows. Acta. Sci. Anim. Sci. 23:923-931.

Shingfield, K. J., L. Bernard, C. Leroux, and Y. Chilliard. 2010. Role of trans fatty acids in the nutritional regulation of mammary lipogenesis in ruminants. Animal 4:1140-1166.

Shiota, M., H. Konishi, and K. Tatsumi. 1999. Oxidative stability of fish oil blended with butter. J. Dairy Sci. 82:1877-1881.

Singleton, V. L. and J. A. Rossi. 1965. Colorimetry of total phenolics with phosphomolybdic-phosphotungstic acid reagents. Am. J. Enol. Vitic. 16:144-158.

Solomon, R., L. E. Chase, D. Ben-Ghedalia, and D. E. Bauman. 2000. The effect of nonstructural carbohydrate and addition of full fat extruded soybeans on the concentration of conjugated linoleic acid in the milk fat of dairy cows. J. Dairy Sci. 83:1322-1329.

Sunvold, G. D., H. S. Hussein, G. C. Fahey, N. R. Merchen, and G. A. Reinhart. 1995. In vitro fermentation of cellulose, beet pulp, citrus pulp, and citrus pectin using fecal inoculum from cats, dogs, horses, humans, and pigs and ruminal fluid from cattle. J. Anim. Sci. 73:3639-3648.
Tyrrell, H. F. and J. T. Reid. 1965. Prediction of the energy value of cow's milk. J. Dairy Sci. 48:1215-1223.

Van Soest, P. J. 1994. Nutrional Ecology of the Ruminant. Cornell University Press, Ithaca, NY, USA.

Voltolini, T. V., G. T. Santos, M. A. Zambom, N. P. Ribas, E. E. Müller, J. C. Damasceno, L. C. V. Ítavo, and D. R. Veiga. 2001 Influence of lactation stages on the counting of somatic cells of Holstein milk cows and identification of sources of mastitis pathogens in cattle. Acta. Sci. Anim. Sci. 23:961-966.

Weiss, W. P. and D. J. Wyatt. 2003. Effect of dietary fat and vitamin e on $\alpha$-tocopherol in milk from dairy cows. J. Dairy Sci. 86:3582-3591.

Williams, R. J., J. P. Spencer, and C. Rice-Evans. 2004. Flavonoids: Antioxidants or signalling molecules? Free Radic. Biol. Med. 36:838-849.

Yang, S. L., D. P. Bu, J. Q. Wang, Z. Y. Hu, D. Li, H. Y. Wei, L. Y. Zhou, and J. J. Loor. 2009. Soybean oil and linseed oil supplementation affect profiles of ruminal microorganisms in dairy cows. Animal 3:1562-1569.

Zhu, Q. Y., R. M. Hackman, J. L. Ensunsa, R. R. Holt, and C. L. Keen. 2002. Antioxidative activities of oolong tea. J. Agric. Food Chem. 50:6929-6934. 